\title{
Efekt sieciowy w wymiarze zaangażowania w organizacji sektora usług zdrowotnych
}

\section{Network effect in the context of commitment in the organization of the health services sector}

\author{
Szymon Jopkiewicz \\ Uniwersytet Jana Kochanowskiego w Kielcach, e-mail: szymon.jopkiewicz@ujk.edu.pl, ORCID 0000-0001-5289-6820
}

\begin{abstract}
Streszczenie
Problematyka organizacji sieciowych w polskiej literaturze przedmiotu jest nadal tematyką nową. Istotne zatem wydaje się badanie relacji sieciowych w usługach zdrowotnych oraz tego, czy interakcja pacjent-lekarz sprzyja powstawaniu efektu sieciowego. Celem artykułu jest zatem charakterystyka efektu sieciowego w wymiarze zaangażowania w sektorze usług zdrowotnych. W badaniu zastosowano metodę sondażu diagnostycznego, narzędziem badawczym zaś, służącym osiągnięciu postawionego celu, była ankieta w pełni ustrukturyzowana, skierowana do pacjentów placówek zdrowotnych posiadających cechy organizacji sieciowej na terenie województwa świętokrzyskiego. Dla analizy organizacji sektora ochrony zdrowia sieciami fundamentalnymi są relacje, ponieważ definiują one charakter komunikowania się pomiędzy ludźmi, grupami i organizacjami, a proces ten determinuje przepływ informacji i dyfuzję wiedzy.
\end{abstract}

Słowa kluczowe: efekt sieciowy, relacje sieciowe, zaangażowanie.

\begin{abstract}
The issue of network organizations in Polish literature of the subject is still a new problem. It is therefore important to examine the network relationships in health services and whether the patient's interaction with the doctor is conducive to the development of a network effect. For the analysis of the organization of the health care sector networks are fundamental relationships because they define the nature of communication between people, groups and organizations, a process that determines the flow of information, the diffusion of knowledge. Progressive commercialization and transformation of the health sector allows to attempt to refer to the network effect and perceive a leading role in its commitment. It can therefore be said that in the health sector, involvement is an economic category, and the relationships that arise at the provider-patient interface can foster a network effect.
\end{abstract}

Keywords: network effect, network relationships, commitment. 


\section{Wstęp}

Problematyka organizacji sieciowych w polskiej literaturze przedmiotu jest nadal tematyką nową i pozostaje nie dość szeroko opisana w obszarze zarówno teoriopoznawczym, jak i empirycznym. Jednak badacze świadomi złożoności i wieloaspektowości zjawiska kładą nacisk na ukierunkowanie badań w ujęciu sektorowym. Działania takie dają szansę na poznanie źródeł sukcesu i porażek organizacji sieciowych. Problem ten wydaje się istotny w odniesieniu do sektora opieki zdrowotnej, ponieważ podlega on intensywnym przeobrażeniom i urynkowieniu, a mimo to jego ocena w świadomości pacjentów, beneficjentów systemu, nadal pozostawia wiele do życzenia.

Zdrowie jednostek jest bowiem szczególnym dobrem ekonomicznym, które ma znaczną wartość determinującą aktywność życiową i zawodową jednostek. Prawem każdego człowieka jest jak najlepsze zdrowie, a tym samym każdy ma prawo do jak najlepszej opieki zdrowotnej, polegającej na świadczeniu profesjonalnych usług przez wyspecjalizowane jednostki, tworzące np. organizacje o charakterze sieciowym.

Zmiany strukturalne i organizacyjne sprawiły, że wzrost efektywności stał się szansą dostosowania sektora zdrowia do nowych społecznych potrzeb. Proces świadczenia usług medycznych w Polsce wszedł w okres „paradygmatycznej niestabilności" [Dobska, Rogoziński 2008, s. 261]. Wiąże się to z nurtem określanym jako nowe zarządzanie publiczne (new public management). W związku z tym strategie transformacji w sektorze ochrony zdrowia ukierunkowane muszą być na konieczność sprostania mechanizmom rynkowym w dostarczaniu dóbr publicznych. Należy zatem poszukiwać takich efektywnych metod zarządzania limitowanymi zasobami, aby zarówno kwestie ekonomiczne, jak i zasady sprawiedliwości społecznej były brane pod uwagę w należytym stopniu [Austen, Frączkiewicz-Wronka 2010, s. 54].

Polskie organizacje sektora usług zdrowotnych o charakterze sieciowym stanowią dość zróżnicowaną formę zarówno organizacyjną, jak i prawną, zdolną do dostosowania się do turbulentnego otoczenia. I jak słusznie zauważa M. Sak-Skowron [2009, s. 61], w swoim dotychczasowym rozwoju i ekspansji rynkowej wykorzystują ograniczenia publicznej służby zdrowia i wypełniają luki tego rynku stwarzane przez regulacje prawne, organizacyjne, sytuację ekonomiczną, społeczną i polityczną. Podjęte natomiast działania integracyjne sprzyjają rozwojowi formalnych więzi.

Powodem podjęcia tematyki związanej z badaniem relacji w sieci jest luka w obrębie opracowań krajowych i zagranicznych, która wynika z faktu, że prowadzone badania empiryczne wciąż nie nadążają za dynamicznymi zmianami w sektorze usług zdrowotnych. Implikuje to konieczność prowadzenia dalszych, pogłębionych analiz, badania związków i ich wzajemnych zależności [Austen, Frączkiewicz-Wronka 2010, s. 55].

Dlatego też istotne wydaje się dociekanie - przy założeniu, że występują struktury sieciowe w polskim sektorze usług zdrowotnych - co jest atrybutem relacji sieciowej oraz czy interakcja pacjent-lekarz sprzyja powstawaniu efektu sieciowego, tym bardziej że nadal brak jest w polskiej literaturze przed- miotu kompleksowych badań poświęconych tej tematyce. Stąd celem niniejszego opracowania jest charakterystyka efektu sieciowego $\mathrm{w}$ wymiarze zaangażowania $\mathrm{w}$ sektorze usług zdrowotnych.

\section{Relacje sieciowe w sektorze usług zdrowotnych}

W sektorze usług zdrowotnych relacje sieciowe mogą powstawać i rozwijać się na płaszczyznach interakcji lekarz-pacjent, ale także lekarz-lekarz czy na poziomie pacjent-pacjent.

Identyfikując podmiot, który mógłby odnosić korzyści z tytułu efektów sieciowych, można dostrzec, że lekarz może pełnić w relacjach sieciowych podwójną rolę, zarówno sprzedawcy produktu sieciowego, świadcząc usługę medyczną oferowaną w ramach sieci medycznej (relacja lekarz-pacjent), jak i nabywcy produktu sieciowego, jakim jest wiedza rozwijana przez pozostałych członków sieci w relacji lekarz-lekarz, gdyż dzielenie się wiedzą polega na rozpowszechnianiu wiedzy w obrębie danej grupy pracowników lub jest transferem tej kategorii zasobu pomiędzy określonymi osobami bądź zespołami pracowników [Probst i in. 2002, s. 177], a lekarz, stając się uczestnikiem sieci medycznej, pozyskuje możliwość szerszych interakcji z gronem specjalistów uczestników relacji sieciowej. Zatem rozwój sieci powinien umożliwić mu jednoczesny rozwój intelektualny przez współtworzenie kultury organizacyjnej promującej zdobywanie wiedzy i dzielenie się nią. Można zatem stwierdzić, że potencjalnie, z punktu widzenia lekarza jako użytkownika sieci, wzrost sieci wynikający z rosnącej liczby lekarzy powinien przysporzyć mu dodatkowych korzyści wynikających nie tylko z rosnącej wartości społecznej sieci, ale także jej użyteczności [Sak-Skowron 2009, s. 61].

Analiza źródeł literaturowych (zastosowana jako wstępny etap procedury badawczej) pozwoliła wyodrębnić trzy atrybuty relacji sieciowych: wymianę, zaangażowanie oraz wzajemność. Typologia wymiany skupia się na przepływach materialnych i energetycznych. Mimo bogatej literatury z zakresu informacyjnego wymiaru przepływów sieciowych, istnieje luka poznawcza w wymiarze badania dostępu do informacji ze względu na przynależność do określonej sieci społecznej [Borgatti, Cross 2003, s. 432-445; Czakon 2015, s. 12]. Poszukiwanie specyfiki wymiany relacyjnej prowadzi do kategorii zaangażowania, rozumianego jako pogłębianie i poszerzanie istniejących relacji wymiany [Anderson, Hakansson, Johanson 1994, s. 3], co czyni zaangażowanie ważnym atrybutem relacji sieciowej. W definicjach wzajemności (reciprocity) pojawia się wspólnota (mutuality). W literaturze można spotkać dwa sposoby rozumienia wzajemności, oparte alternatywnie na władzy lub na wspólnocie. Badania empiryczne dowodzą, że wzajemność przy podziale korzyści gospodarczych jest warunkiem trwania współpracy [Czakon 2015, s. 12].

Badanie sieci daje też szansę na poznanie zależności pomiędzy centralną pozycją organizacji a jej wpływem na całość działań wchodzących w jej skład podmiotów. Zapewne jest to także forma zrozumienia przyczyn sukcesu i porażki danej organizacji, gdyż uwzględnia czynniki pozamerytoryczne oraz niepoddające się zwykłej codziennej obserwacji [Adamus-Ma- 
tuszyńska 2013, s. 14]. Kolejny istotny nurt badań nad sieciami w naukach o zarządzaniu przyjmuje perspektywę socjologiczną przez analogię do sieci społecznych oraz ze względu na ich ścisłe powiązanie z aktywnością gospodarczą człowieka. W wielu aspektach ta analogia okazuje się co najmniej inspirująca, a często także wprost uprawniona. Socjologiczne badania nad sieciami opierają się na przeświadczeniu, że zachowania ludzkie są społecznie uwarunkowane, a cechy społeczności wpływają zarówno na zachowania, jak i na efekty działań człowieka. Przejawy tego uwarunkowania są jednak ważne przede wszystkim dla nauk o zarządzaniu. Istotne jest dociekanie, w jaki sposób sieci otwierają przed organizacjami możliwości uzyskania i utrzymania przewagi konkurencyjnej. Badania sieci skupiają uwagę na strukturalnych aspektach, chętnie wykorzystywanych także w naukach o zarządzaniu [Klimas 2011, s. 83-89]. Pośród nich najbardziej popularne jest badanie całej sieci przez miary wielkości sieci - mierzonej liczbą węzłów; gęstości sieci - mierzonej liczbą powiązań, i heterogeniczności - mierzonej różnorodnością węzłów i powiązań. Ponadto przedmiotem badań jest pozycja konkretnej organizacji w sieci ze względu na jej powiązanie z innymi w przekonaniu, że centralność daje przewagę, podczas gdy peryferyjność obniża szanse rozwojowe, choć chroni też przed niektórymi zagrożeniami [Czakon 2015, s. 12]. Biorąc pod uwagę specyfikę organizacji sektora zdrowia, można założyć, że badanie sieci jest potrzebne do wzmocnienia odpowiedzialności i przejrzystości, uwypuklając nie tylko koszty aktywności publicznych (wydatki NFZ), ale także uzyskiwane wyniki. Badanie relacji sieciowych może stanowić $\mathrm{w}$ warunkach konkurencyjności podstawę do dokonywania racjonalnych metodologicznie wyborów, spełniając funkcje podobne do roli ceny w mechanizmach rynkowych [Ferlie i in. 2003, s. 1-14; Austen, Frączkiewicz-Wronka 2010, s. 57]. Specyfika organizacji sektora zdrowia wynika z systemowego ujmowania usług zdrowotnych, które zalicza się do kategorii usług profesjonalnych. Kryterium wyodrębnienia wynika nie z branżowej klasyfikacji usług, ale z zaangażowania specjalistów w proces usługowy [Thomas 1978, s. 161]. Wśród teoretyków brak jest zgodności co do definicji usług profesjonalnych. Imse uwypukla specyficzne cechy grupy zawodowej, jaką są profesjonaliści, i wymienia takie cechy, jak: specyficzna wiedza, imperatyw permanentnego podnoszenia swoich kwalifikacji, działanie oparte na własnym rozsądku i etyce altruizmu oraz wpływ na życie innych [Imse 1962, s. 24].

Badania relacji sieciowych będą miały wkład teoriopoznawczy w dorobek nauk o zarządzaniu, a szczególnie zarządzania strategicznego w sektorze publicznym [Austen, Frączkiewicz-Wronka 2010, s. 57; Czakon 2015, s. 12]. Dla analizy organizacji sektora ochrony zdrowia sieciami fundamentalne są relacje, ponieważ definiują one charakter komunikowania się pomiędzy ludźmi, grupami i organizacjami, a proces ten determinuje przepływ informacji, dyfuzję wiedzy.

\section{Efekt sieciowy $w$ wymiarze zaangażowania organizacyjnego $\mathrm{w}$ świetle badań}

Efekt sieciowy jest atrybutem sieci, który sprawia, że posiadanie przez potencjalnego klienta dobra lub korzystanie z usługi stanowi dla niego wartość zależną od liczby klientów, którzy podobnie jak on mają dany produkt lub korzystają z konkretnej usługi. Zatem im większa liczba klientów korzystających z usługi, tym wyższa wartość użytkowa dla jej przyszłych użytkowników. Zmiany w wartości dobra lub usługi należy rozumieć jako zmiany w użyteczności całkowitej, jaką dobru lub usłudze przypisuje konsument. Wobec tego użyteczność dobra zależy od liczby konsumentów będących w tej samej sieci (odnoszącej się do tego samego dobra) [Katz, Shapiro 1985, s. 426]. Wzrost liczby użytkowników danego dobra lub usługi powoduje wzrost użyteczności.

Odnosząc efekt sieciowy do sektora zdrowia, należy stwierdzić, że relacje usługowe pacjent-lekarz mogą być uznane za te, które tworzą relacje sieciowe i podtrzymują ich wartość, opierając się na zaangażowaniu, wzajemności i wymianie. Niemniej jednak relacje usługowe pacjent-lekarz charakteryzuje duże zaangażowanie, dlatego też $\mathrm{w}$ analizie empirycznej skupino się na tym atrybucie relacji sieciowej, który najsilniej determinuje zaistnienie efektu sieciowego.

Pojęcie zaangażowania bywa często mylnie identyfikowane z „przywiązaniem”. W.L. Wilkie [1995, s. 164] zaangażowanie konsumenta (consumer involvment) definiuje jako „ilość wydatkowanej przez konsumenta energii na określoną aktywność związaną z nabywaniem i honorowaniem dóbr i usług". Zatem zaangażowanie ma podłoże motywacyjne, gdyż pobudza konsumentów do działania i ukierunkowuje ich zachowania.

Immanentną cechą zaangażowania jest to, że jego poziom zmienia się w zależności od konkretnej sytuacji (rodzaju interakcji). Zwykle nowa usługa powoduje wzrost zaangażowania konsumentów, a tym samym modyfikację ich zachowań [Furtak 2003, s. 175]. Ranga zaangażowania z perspektywy strony popytowej relacji uzasadnia siłę identyfikacji pacjenta z celami i zadaniami wyznaczonymi przez usługodawcę $w$ procesie diagnozy i terapii. Spośród wielu typów zaangażowania (afektywne, normatywne i intencjonalne) tylko afektywnemu przypisuje się wpływ na stopień, w jakim pacjent zamierza wytrwać i kontynuować relację z usługodawcą [Roberts, Varki, Broslie 2003, s. 178].

Relacja usługowa jest wynikiem dużej intensywności interakcji usługodawca-pacjent oraz relatywnie długiego okresu jej trwania, sprzyjającego pojawieniu się uczucia bliskości i pewnego rodzaju zażyłości [Rudawska 2007, s. 73]. Ponadto takie cechy usługodawcy, jak reagowanie, umiejętność słuchania i wyjaśniania, próby zrozumienia argumentów drugiej strony oraz empatia, są warunkiem nawiązania względnie trwałej relacji [Chandon, Leo, Philippe 1997, s. 67]. Dowodzą tego, że pacjent, komunikując się, zdaje się na kontakt z konkretną osobą $\mathrm{i}$ istotną rolę odgrywają w tej relacji związki emocjonalne.

Warunkiem niezbędnym do zaistnienia zaangażowania w relację jest postrzeganie jej przez strony w kategoriach ważności. Zaangażowanie można interpretować jako afektywne przywiązanie klienta do organizacji. Intensywność tego przywiązania może wahać się w zależności od typu relacji. Relacje o dużym udziale elementów ekspresywnych, czyli większość związków usługodawca-pacjent, są bardziej podatne na wystąpienie zjawiska zaangażowania. Jego rola wzrasta wraz ze stopniem złożoności usługi zdrowotnej i brakiem kompetencji dokona- 
nia przez pacjenta profesjonalnej oceny wykonanej usługi [Rudawska 2004, s. 15-16].

R. Brody twierdzi, że zwiększenie udziału pacjentów w podejmowaniu decyzji klinicznych poprawi opiekę nad chorymi i wyniki leczenia dzięki lepszemu gromadzeniu informacji, trafności decyzji, wykorzystaniu przez lekarzy technologii, zainteresowaniu pacjenta kosztami, niewygodami, dolegliwościami oraz komplikacjami towarzyszącymi zbiegom [Brody 1980, s. 719].

Włączanie pacjenta w podejmowanie decyzji zmusza lekarza do wzięcia pod uwagę wszystkich możliwości i przedstawienia uzasadnienia zaleceń. Pacjent, rozumiejąc naturę problemu, potrafi ustosunkować się do fundamentów rozumowania lekarza. Wymiana poglądów winna prowadzić do bardziej racjonalnego, właściwego i otwartego rozważania wszystkich sposobów leczenia [Brody 1980, s. 721].

Zaangażowanie wpływa na jakość relacji poprzez kształtowanie postaw i zachowań lekarza oraz pacjenta. Istotność zaangażowania dla podażowej strony relacji należy łączyć ze zmniejszoną rotacją pracowników, większą ich motywacją, umacnianiem systemu wartości organizacji, co zwiększa skuteczność działań. Z perspektywy strony popytowej relacji wagę zaangażowania uzasadnia siła identyfikacji pacjenta z celami i zadaniami wyznaczonymi przez lekarza $\mathrm{w}$ relacji usługowej [Rudawska 2004, s. 16]. Ponadto proces komunikowania się oraz budowania związków pomiędzy jednostkami sprzyja dzieleniu się wiedzą przez członków organizacji, a to może sprzyjać powstawaniu efektu sieciowego.

\section{Charakterystyka efektu sieciowego w wymiarze zaangażowania}

W badaniu zastosowano metodę sondażu diagnostycznego, narzędziem badawczym zaś, służącym uzyskaniu odpowiedzi na postawiony cel, była ankieta $\mathrm{w}$ pełni ustrukturyzowana, skierowana do pacjentów placówek zdrowotnych posiadających cechy organizacji sieciowej na terenie województwa świętokrzyskiego. Dobór próby miał charakter losowy, prosty, tzn. każdy element miał szansę trafienia do próby [Churchil 2002, s. 504-505]. Operatem losowania był rejestr zakładów opieki zdrowotnej województwa świętokrzyskiego. Za pomocą tablic liczb przypadkowych (oprogramowanie Office Excel 7.0) zostało wytypowane 21 placówek, w których wykorzystano technikę ankiety rozdawanej, co pozwoliło na uzyskanie zwrotu w przedziale 10-15 sztuk w zależności od placówki. Taka forma dystrybucji ankiety badawczej pozwoliła przy stosunkowo niedużym koszcie finansowym uzyskać zadowalający poziom zwrotu (35\%) oraz krótki czas pomiaru.

Badana grupa była zróżnicowana pod względem miejsca zamieszkania, wieku i wykształcenia, a także płci. Cechy te wpłyną na zróżnicowanie opinii, wniosków w obszarze zagadnieniowym, co przyczyni się do pełniejszego zobrazowania zjawiska. W sumie za pomocą kwestionariusza ankiety przebadano 195 kobiet oraz 84 mężczyzn. Respondenci zgodnie z przyjętym celem badania mieli za zadanie odpowiedzieć na pytania określające poziom istotności danego zjawiska dla za- angażowania lekarza i pacjenta w relacji sieciowej (tab. 1 i 2 ) oraz formy komunikacji budujące relacje sieciowe (tab. 3).

Postawione respondentom pytania badawcze dotyczyły kluczowych parametrów opisujących zaangażowanie w proces usługowy po stronie zarówno lekarza, jak i pacjenta (tab. 1 i 2 ).

Tabela 1. Zaangażowanie pacjenta w relację usługową

\begin{tabular}{|l|c|c|c|c|c|}
\hline \multicolumn{1}{|c|}{ Opinia } & $\begin{array}{c}\text { Zupełnie } \\
\text { nieważne }\end{array}$ & $\begin{array}{c}\text { Raczej } \\
\text { nieważne }\end{array}$ & $\begin{array}{c}\text { Ani ważne, } \\
\text { ani } \\
\text { nieważne }\end{array}$ & $\begin{array}{c}\text { Dość } \\
\text { ważne }\end{array}$ & $\begin{array}{c}\text { Bardzo } \\
\text { ważne }\end{array}$ \\
\hline $\begin{array}{l}\text { Dostosowanie } \\
\text { się do zaleceń } \\
\text { lekarza }\end{array}$ & $1,08 \%$ & $0,36 \%$ & $1,43 \%$ & $33,33 \%$ & $63,80 \%$ \\
\hline $\begin{array}{l}\text { Współpraca } \\
\text { z lekarzem }\end{array}$ & $0,36 \%$ & $1,79 \%$ & $1,08 \%$ & $37,99 \%$ & $58,78 \%$ \\
\hline $\begin{array}{l}\text { Przywiązanie } \\
\text { do lekarza }\end{array}$ & $2,87 \%$ & $14,70 \%$ & $32,97 \%$ & $41,22 \%$ & $8,24 \%$ \\
\hline $\begin{array}{l}\text { Rola pacjenta } \\
\text { w procesie } \\
\text { diagnozy }\end{array}$ & $0,36 \%$ & $5,38 \%$ & $11,11 \%$ & $52,33 \%$ & $30,82 \%$ \\
\hline $\begin{array}{l}\text { Akceptacja } \\
\text { zaleceń } \\
\text { lekarza }\end{array}$ & $0,72 \%$ & $0,72 \%$ & $2,51 \%$ & $48,03 \%$ & $48,03 \%$ \\
\hline $\begin{array}{l}\text { Akceptacja } \\
\text { odczuć } \\
\text { pacjenta }\end{array}$ & $1,08 \%$ & $2,87 \%$ & $7,17 \%$ & $53,41 \%$ & $35,48 \%$ \\
\hline $\begin{array}{l}\text { Więź } \\
\text { emocjonalna } \\
\text { (sympatia) }\end{array}$ & $7,17 \%$ & $12,54 \%$ & $29,03 \%$ & $37,99 \%$ & $13,26 \%$ \\
\hline $\begin{array}{l}\text { Motywacja } \\
\text { pacjenta } \\
\text { do leczenia }\end{array}$ & $1,08 \%$ & $1,79 \%$ & $5,02 \%$ & $40,14 \%$ & $51,97 \%$ \\
\hline
\end{tabular}

Źródło: opracowanie własne.

Odpowiedzi respondentów wskazują na istotną rolę sfery kognitywnej, czyli więzi opartych na wiedzy, a także więzi psychologicznych, czyli sfery afektywnej (np. sympatia, empatia, akceptacja osoby pacjenta) jako czynników budujących zaangażowanie, po stronie zarówno pacjenta, jak i lekarza przedstawiciela organizacji, w budowaniu relacji sieciowej. Anderson i in. [1994, s. 3] dostrzegli, iż specyfika wymiany relacyjnej prowadzi do kategorii zaangażowania, rozumianego jako pogłębianie i poszerzanie istniejących relacji wymiany, co podkreśla rolę zaangażowania jako ważnego atrybutu relacji sieciowej. Na to również wskazują uzyskane wyniki analizy zaangażowania lekarza $\mathrm{w}$ relację usługową, tj.: zrozumienie i zainteresowanie osobą pacjenta (94\%), akceptacja osoby chorego (blisko 90\% odpowiedzi badanych w kategorii dość ważne i bardzo ważne), czas poświęcony pacjentowi (95\%) oraz gotowość do słuchania (92\%).

Przepływ informacji pomiędzy lekarzem i pacjentem, ich obopólne zaangażowanie w relację usługową, włączenie pacjenta w proces diagnozy $(92 \%)$, zainteresowanie osobą pacjenta (95\%), umiejętność dzielenia się wiedzą (87\%) stają się ważnymi elementami utrzymującymi pacjenta w placówce i stanowią dowód na istotną rolę zaangażowania w kształtowaniu efektu sieciowego w sektorze usług zdrowotnych. 
Tabela 2. Zaangażowanie lekarza w relację usługową

\begin{tabular}{|c|c|c|c|c|c|}
\hline Opinia & $\begin{array}{l}\text { Zupełnie } \\
\text { nieważne }\end{array}$ & $\begin{array}{l}\text { Raczej } \\
\text { nieważne }\end{array}$ & $\begin{array}{l}\text { Ani ważne, } \\
\text { ani nieważne }\end{array}$ & Dość ważne & Bardzo ważne \\
\hline Umiejętność dzielenia się wiedzą & $0,72 \%$ & $2,87 \%$ & $8,96 \%$ & $43,01 \%$ & $44,44 \%$ \\
\hline Kierowanie pacjenta do specjalistycznej placówki współpracującej & $0,72 \%$ & $1,43 \%$ & $6,45 \%$ & $50,90 \%$ & $40,50 \%$ \\
\hline Zaangażowanie lekarza w kontakcie z pacjentem & $0,00 \%$ & $0,36 \%$ & $2,51 \%$ & $36,92 \%$ & $60,22 \%$ \\
\hline Akceptacja odczuć pacjenta & $1,08 \%$ & $2,87 \%$ & $7,17 \%$ & $53,41 \%$ & $35,48 \%$ \\
\hline Zaangażowanie personelu medycznego & $0,36 \%$ & $2,51 \%$ & $11,11 \%$ & $51,61 \%$ & $34,41 \%$ \\
\hline $\begin{array}{l}\text { Wyjaśnianie i instruowanie w diagnozie - włączanie pacjenta } \\
\text { w proces diagnozy }\end{array}$ & $1,79 \%$ & $1,08 \%$ & $4,30 \%$ & $43,37 \%$ & $49,46 \%$ \\
\hline Przekazywanie informacji o stanie zdrowia pacjenta & $0,36 \%$ & $0,00 \%$ & $1,43 \%$ & $24,01 \%$ & $74,19 \%$ \\
\hline Empatia (współodczuwanie) ze strony lekarza & $4,30 \%$ & $11,11 \%$ & $29,39 \%$ & $40,14 \%$ & $15,05 \%$ \\
\hline Więź emocjonalna (sympatia) & $7,17 \%$ & $12,54 \%$ & $29,03 \%$ & $37,99 \%$ & $13,26 \%$ \\
\hline Zrozumienie i zainteresowanie osobą pacjenta & $1,08 \%$ & $0,72 \%$ & $3,94 \%$ & $40,14 \%$ & $54,12 \%$ \\
\hline Ułatwienie pacjentowi wypowiadania się & $1,43 \%$ & $1,43 \%$ & $7,89 \%$ & $49,46 \%$ & $39,78 \%$ \\
\hline Akceptacja osoby chorego & $1,43 \%$ & $1,08 \%$ & $2,15 \%$ & $40,50 \%$ & $54,84 \%$ \\
\hline Gotowość do słuchania & $1,08 \%$ & $0,72 \%$ & $5,73 \%$ & $45,16 \%$ & $47,31 \%$ \\
\hline Okazywanie współczucia & $2,15 \%$ & $10,04 \%$ & $27,24 \%$ & $45,52 \%$ & $15,05 \%$ \\
\hline Kontakt wzrokowy z pacjentem & $1,43 \%$ & $4,30 \%$ & $11,83 \%$ & $53,05 \%$ & $29,39 \%$ \\
\hline Zrozumiałość wypowiedzi & $1,08 \%$ & $1,79 \%$ & $2,15 \%$ & $45,88 \%$ & $49,10 \%$ \\
\hline Czas poświęcony pacjentowi & $0,72 \%$ & $1,79 \%$ & $6,09 \%$ & $41,94 \%$ & $49,46 \%$ \\
\hline Przekazywana wiedza lekarza o metodach leczenia & $0,36 \%$ & $1,08 \%$ & $2,87 \%$ & $29,39 \%$ & $66,31 \%$ \\
\hline Precyzja przekazu zaleceń przez lekarza & $1,08 \%$ & $0,72 \%$ & $4,66 \%$ & $32,26 \%$ & $61,29 \%$ \\
\hline
\end{tabular}

Źródło: opracowanie własne.

Tabela 3. Formy komunikacji w relacji usługowej budujące sieciowość

\begin{tabular}{|c|c|c|c|c|c|}
\hline Opinia & $\begin{array}{l}\text { Zupełnie } \\
\text { nieważne }\end{array}$ & $\begin{array}{c}\text { Raczej } \\
\text { nieważne }\end{array}$ & $\begin{array}{l}\text { Ani ważne, } \\
\text { ani nieważne }\end{array}$ & Dość ważne & Bardzo ważne \\
\hline Bezpośredni kontakt z lekarzem & $0,72 \%$ & $3,23 \%$ & $3,94 \%$ & $38,35 \%$ & $53,76 \%$ \\
\hline Bezpośredni kontakt z personelem & $2,51 \%$ & $15,05 \%$ & $24,37 \%$ & $46,24 \%$ & $11,83 \%$ \\
\hline Kontakt telefoniczny z lekarzem & $3,23 \%$ & $12,19 \%$ & $18,28 \%$ & $46,24 \%$ & $20,07 \%$ \\
\hline Kontakt telefoniczny z personelem & $8,96 \%$ & $21,86 \%$ & $26,16 \%$ & $36,56 \%$ & $6,45 \%$ \\
\hline Kontakt za pomocą Internetu z lekarzem & $16,85 \%$ & $25,45 \%$ & $30,47 \%$ & $22,22 \%$ & $5,02 \%$ \\
\hline Kontakt za pomocą Internetu z placówką medyczną & $11,11 \%$ & $18,64 \%$ & $31,54 \%$ & $30,47 \%$ & $8,24 \%$ \\
\hline Bezpośredni kontakt z innymi pacjentami & $4,30 \%$ & $32,62 \%$ & $32,26 \%$ & $15,05 \%$ & $15,77 \%$ \\
\hline $\begin{array}{l}\text { Kontakt z innymi pacjentami za pomocą Internetu (listy dyskusyjne, } \\
\text { fora i czaty internetowe nt. placówki medycznej i lekarzy specjalistów) }\end{array}$ & $5,73 \%$ & $18,28 \%$ & $27,96 \%$ & $26,88 \%$ & $21,15 \%$ \\
\hline
\end{tabular}

Źródło: opracowanie własne.

Analiza zaangażowania po stronie pacjenta w relacji sieciowej ujawnia, iż elementami warunkującymi jej funkcjonowanie są m.in. współpraca z lekarzem (96\%), włączanie w proces diagnozy (82\%), akceptacja odczuć pacjenta (88\%), co znajduje potwierdzenie także w badaniach. Roberts i in. [2003] uznali, że zaangażowanie stanowi istotny wyznacznik relacji usługowych [Roberts, Varki, Broslie 2003, s. 178]. A trzy główne cechy charakteryzujące silne zaangażowanie organizacyjne [Cohen 2007, s. 338], czyli akceptacja celów i wartości organizacyjnych (pacjenci i lekarze), wysoka skłonność do podejmowania wysiłku na rzecz organizacji (lekarze i personel medyczny), silne pragnienie przynależności do organizacji (pacjenci, lekarze i personel medyczny), determinują również powstanie relacji sieciowych pomiędzy stronami relacji usługowej.

Problem utrzymania zaangażowania dotyczy nie tylko procesu leczenia, ale całego procesu zarządzania i świadczenia usług przez podmioty sektora zdrowia. Stąd organizacje sektora zdrowia, chcąc utrzymać odpowiedni wymiar zaangażowania, winny kształtować efekt sieciowy w wymiarze komunikacyjnym dzięki efektywnym formom kontaktu pacjenta z placówką i personelem, m.in. przez wskazanie na bezpośrednie relacje z lekarzem (91\%), kontakt telefoniczny z lekarzem (66\%), kontakt z innymi pacjentami poprzez Internet (fora, czaty, listy dyskusyjne, opinie), na co wskazuje $68 \%$ badanych. 
Pojęcie zaangażowania (commitment) wywodzi się z teorii wymiany społecznej. W teorii tej zakłada się, że to, co ludzie sądzą (pozytywnego czy negatywnego) o swoim związku z inną osobą, będzie zależało od tego, jak pojmują nagrody, które daje im ten związek, koszty, na jakie się narażają, co sądzą o tym, na jaki związek zasługują, i jakie jest ich zdaniem prawdopodobieństwo nawiązania lepszych stosunków z kimś innym [Aronson,Wilson, Akert 1997, s. 426-427]. Interpretując teorię wymiany społecznej, można zatem powiedzieć, że w systemie ochrony zdrowia zaangażowanie jest kategorią społeczną, a zarazem ekonomiczną i stanowi ważną determinantę usieciowienia oraz transformacji sektora zdrowia.

\section{Zakończenie}

Postępujące urynkowienie i transformacja sektora usług zdrowotnych pozwala na próbę odniesienia do efektu sieciowego i dostrzeżenia dominującej w nim roli zaangażowania. Można zatem powiedzieć, że w sektorze zdrowia zaangażowanie jest kategorią ekonomiczną, a relacje powstające na styku usługodawca-pacjent mogą sprzyjać efektowi sieciowemu.

Zaangażowanie wpływa na jakość relacji poprzez kształtowanie postaw i zachowań lekarza oraz pacjenta. Istotność zaangażowania dla podażowej strony relacji należy łączyć ze zmniejszoną rotacją pracowników, większą ich motywacją, umacnianiem systemu wartości organizacji, co zwiększa skuteczność działań przy redukcji kosztów działania systemu. Z perspektywy strony popytowej relacji wagę zaangażowania uzasadnia siła identyfikacji pacjenta z celami i zadaniami wyznaczonymi przez lekarza w relacji usługowej [Rudawska 2004, s. 16]. Korzyści dostrzegane przez klientów sieci mają głównie charakter społeczny bezpośredni (relacje między pacjentami pozwalają zaoszczędzić czas i pieniądze), pośredni (w postaci krótszego czasu leczenia w wyniku pełniejszej wiedzy lekarzy) lub negatywny (spadek dostępności lekarzy wraz z przyrostem liczby pacjentów) [Sak-Skowron 2009, s. 63].

Ponadto proces komunikowania się oraz budowania związków pomiędzy jednostkami sprzyja dzieleniu się wiedzą przez członków organizacji, a to może sprzyjać powstawaniu efektu sieciowego. Badanie efektów sieciowych pozwala na odkrycie trudno zauważalnych cech struktur sieci sektora zdrowia i wymaga dalszych pogłębionych badań i analiz.

\section{Literatura}

Adamus-Matuszyńska A., 2013, Wykorzystanie SNA w pomiarze efektywności instytucji publicznych, [w:] Efektywność zarządzania organizacjami publicznymi i jej pomiar, red. A. Frączkiewicz-Wronka, Zeszyty Naukowe Wydziałowe UE w Katowicach.

Anderson J.C., Håkansson H., Johanson J., 1994, Dyadic business relationships within a business network context, Journal of Marketing, vol. 58.

Aronson E., Wilson T.D., Akert R.M., 1997, Psychologia społeczna. Serce i umysł, Zysk i S-ka, Poznań, s. 426-427.
Austen A., Frączkiewicz-Wronka A., 2010, Pragmatyka pomiaru efektywności organizacji publicznej na przykładzie sektora ochrony zdrowia, [w:] Studia i Prace Kolegium Zarządzania i Finansów, Zeszyt Naukowy nr 98, Szkoła Główna Handlowa w Warszawie, Warszawa.

Borgatti S.P., Cross R., 2003, A relational view of information seeking and learning in social networks, Management Science, vol. 49, $\mathrm{nr} 4$, s. $432-445$.

Brody R., 1980, The patients role In clinical decision-making, Ann. Int. Med., 93, s. 718-722.

Chandon J., Leo P., Philippe J., 1997, Service encounter dimensions: a dyadic perspective, International Journal of Service Industry Management", vol. 8, no. 1 .

Churchil G.A., 2002, Badania marketingowe. Podstawy metodologiczne, PWN, Warszawa.

Cohen A., 2007, Commitment before and after: an evaluation and reconceptualization of organizational commitment, Human Resource Management Review, 17, 3, s. 336-354.

Czakon W., 2015, Sieci międzyorganizacyjne w naukach o zarządzaniu - $w$ kierunku sieciowych modeli biznesu, Studia Ekonomiczne, Zeszyty Naukowe Uniwersytetu Ekonomicznego w Katowicach nr 217, Katowice.

Dobska M., Rogoziński K., 2008, Podstawy zarządzania zakładem opieki zdrowotnej, PWN, Warszawa.

Ferlie E., Hartley J., Martin S., 2003, Changing public service organizations: Current perspectives and future prospects, British Journal of Management, vol. 14.

Furtak R., 2003, Marketing partnerski na rynku usług, PWE, Warszawa.

Imse T., 1962, The professionalization of business management, Vantage Press, New York.

Katz M.L., Shapiro C., 1985, Network externalities, competition and compatibility, The American Economic Review, vol. 75, no. 3.

Klimas P., 2011, Sukces sieci miẹdzyorganizacyjnej, Prace i Materiały Wydziału Zarządzania Uniwersytetu Gdańskiego, nr 4.

Probst G., Raub S., Romhardt K., 2002, Zarządzanie wiedza w organizacji, Oficyna Ekonomiczna, Kraków.

Roberts K., Varki S., Broslie R., 2003, Measuring the quality of relationship in consumer services an empirical study, European Journal of Marketing, vol. 37, no. 1-2.

Rudawska I., 2004, Kształtowanie zaangażowania $w$ relacjach usługowych (na przykładzie rynku usług zdrowotnych), Marketing i Rynek, 3, s. 15-16.

Rudawska I., 2006, Ekonomizacja relacji pacjent-usługodawca w opiece zdrowotnej, Uniwersytet Szczeciński, Szczecin.

Rudawska I., 2007, Opieka zdrowotna. Aspekty rynkowe i marketingowe, PWN, Warszawa

Sak-Skowron M., 2009, Sieci, sieci medyczne i efekty sieciowe w służbie zdrowia, Master of Business Administration, 3(98), maj-czerwiec, Warszawa.

Wilkie W.L., 1995, Customer behavior, Journal of Services Marketing, vol. 9 , no. 1 . 